DOI https://doi.org/10.36059/978-966-397-242-8-5

\author{
Мамчич I. П., \\ кандидат філологічних наук, доцент, \\ доцент кафедри гуманітарної підготовки, філософії \\ та митної ідентифікації культурних цінностей \\ Університету митної справи та фінансів, \\ м. Дніпро
}

\title{
ПОРІВНЯЛЬНИЙ АНАЛІЗ АНТОНІМІЧНОГО ПРОТИСТАВЛЕННЯ У ТВОРАХ МАРИНИ ГРИМИЧ, ОКСАНИ ЗАБУЖКО, МАРІЇ МАТІОС
}

Анотація. На сучасному етапі розвитку мовознавства значну увагу дослідники приділяють семантиці слів, так чи так протиставлювальних у мовній системі. Антонімія як складне й багатоаспектне лексико-семантичне явище постає під час взаємодіі позамовних категорій, концептів мислення та мовних одиниць.

Мова художньої літератури максимально актуалізує виразові можливості полісемічних слів-антонімів і найповніше антонімічносинонімічну взаємодію лексичних одиниџь, тому постало завдання дослідити явище антонімії у художніх творах сучасних українських письменниць Марини Гримич, Оксани Забужко, Марії Матіос. На підставі класифікацій антонімів за семантикою (застосовано різноманітні класифікації, а не лише традиційну (градуальні, комплементарні, векторні та конверсиви), структурою, частиномовною належністю, уживаністю виявлено основні тенденції ідіостилю авторок, здійснено порівняльний аналіз. Стилетвірною ознакою ідіолекту Марини Гримич постають контекстуальні антоніми-іменники (забаганка - покликання, прокляття - обов'язок, герой - пішак. Особливістю тексту «Солодкої Дарусі» М. Матіос уважаємо прикметникові контекстуальні антоніми (Даруся не дурна - солодка, що можна пояснити тематичним спрямуванням роману. У творі О. Забужко простежити закономірності семантичного вживання контекстуальних антонімів важко.

\section{Вступ}

Для сучасної лінгвістики характерна посилена увага до проблем лексичної семантики, дослідження яких дає змогу глибше усвідомити 
такі складні теоретичні питання, як співвідношення мови й позамовного світу, мови й мислення. Одна $з$ основних і найменш вивчених категорій лексико-семантичної системи - антонімія. Номінації, які репрезентують антонімічні відношення, - наслідок відображення в мові суперечливої сутності різних явищ і результат вираження реальних протилежностей об'єктивної дійсності.

Антонімію на матеріалі белетристики української та російської мов, як поезії, так і прози, досліджували Н. М. Бобух [2; 3], В. А. Василенко [4], О. М. Калита [6], В. П. Коваль [7], В. П. Ковальов [8], К. В. Тараненко [13; 14], О. Д. Тарасенко [15] та інші.

Утім, багато питань лексичної антонімії перебувають поза увагою сучасних дослідників. Зокрема, усе ще недостатньо досліджено мову сучасної української жіночої прози. Явище антонімії у творчості М. Гримич, О. Забужко, М. Матіос потребує подальшого аналізу, що зумовлює актуальність нашого дослідження. Його результати можуть бути корисними під час подальшого аналізу як поетичних, так і прозових творів названих письменниць.

Meта роботи - дослідити вияв явища антонімії в художніх творах сучасних українських письменниць, зокрема Марини Гримич, Оксани Забужко, Марії Матіос. Для досягнення цієї мети потрібно виконати такі завдання: подати структурну, морфологічну й функційно-семантичну класифікацію антонімів; з'ясувати стилістичне використання антонімів у мові творів М.Гримич, 0.Забужко, М. Матіос; визначити спільне і відмінне у вживанні контекстуальних антонімів у текстах названих письменниць.

Матеріалом дослідження слугували антонімічні пари кількістю близько 280 одиниць, дібрані 3 творів «Фріда» М. Гримич, «Польові дослідження з українського сексу» О. Забужко та «Солодка Даруся» М. Матіос.

Антоніми виникають, функціонують, розвиваються в мовленні, утворюють антонімічні опозиції. Антонімічні відношення охоплюють всю систему номінації, тобто антонімічність постає внутрішньою фундаментальною властивістю мови. Ці відношення реалізуються (виникають) лише в мовленні. Клас антонімів безперервно зростає, змінюється, не має чітких меж, носить відкритий характер.

Антонімія як явище має парадоксальну природу: з одного боку, значення лексичних одиниць грунтуються на абсолютній протилежності, а з іншого - це найтісніші семантичні зближення в лексиці. В описі мовної та мовленнєвої сутності антонімії виявлено 
певну плутанину через те, що дослідники цього явища переважно визначають межі протилежності слів, керуючись здебільшого інтуїцією, а не чітко окресленими нормами. Донедавна антонімами вважали лише слова, що містять у своєму значенні вказівку на якість. Сучасні науковці вбачають антонімію і в словах, що належать до тієї самої частини мови та позначають різноманітні відчуття, дії, стан, оцінку, просторові та часові відношення тощо, тобто поступово більше зміцнюється широке розуміння антонімії.

Вихідним у нашому дослідженні $\epsilon$ визначення антонімів як регулярно протиставлюваних у мові й мовленні лексем, які позначають взаємно протилежні (наявність контрарних сем) співвідносні (наявність спільної семи) предмети, властивості й процеси об'єктивної дійсності. за допомогою контрастного зіставлення фактів найяскравіше вимальовується їхня глибина, бо на темному тлі найчіткіше видніється ясне, звучання чудово сприймається в тиші, знайшовши кінець чомусь підсвідомо шукаємо його початок. Регулярне протиставлення антонімів один одному спричиняє те, що кожен з них викликає в нашій свідомості уявлення про свою протилежність. Утім, поняття антонімів може розширюватися за рахунок контекстуальних одиниць.

Антоніми потрапляють до стилістичних засобів як завдяки своїм внутрішнім семантичним властивостям, так і завдяки тому, що антонімічні протиставлення не $є$ чимось застиглим, обмеженим i мовець може вживати антонімічні слова не лише за усталеною в лінгвальному обігу схемою, а й залежно від особливостей власного, індивідуального світосприймання. Семантичні відношення між антонімами не завжди бувають нерозривними і здебільшого антонімічні відношення пов'язують 3 певними стилістичними функціями, що їх виконують слова-антоніми в контексті. Антоніми сприяють підсиленню певного поняття.

Антоніми $€$ лінгвістичною універсалією, котра породжена суб'єктивними мовотворчими зусиллями мовця в його пошуках експресивних засобів вислову. Мова художньої літератури максимально актуалізує потенції полісемічних слів-антонімів і найповніше антонімічно-синонімічну взаємодію лексичних одиниць.

\section{Семантичні класифікації антонімів у романах письменниць}

Класифікуючи антоніми у художніх творах Марини Гримич, Оксани Забужко та Марії Матіос за характером протиставлення, 
дотримуємося прийнятого в мовознавстві їх поділу на градуальні (контрарні), комплементарні та векторні.

Характерною особливістю контрарних антонімічних пар $є$ те, що вони об'єднують слова, які виявляють градуальність опозицій, яка вказує на різний ступінь прояву ознаки. Градуальні антоніми $є$ найбільшим класом слів з протилежним значенням, що позначають два діаметрально про протилежні (за мірою або ступенем вияву) видові поняття певного родового поняття [11, с. 81].

Контрарні антоніми в аналізованих творах позначають:

1. Різноманітні дії як істот, так і неістот: Як зненацька з'явився я у Вашому житті, так і зникну з нього - раптово і безслідно (1, с. 92), ...nо тій страшній кембриджській зимі, як повільно, з тиждень на тиждень вимерзла, вмерзла в непролазні сніги, витікаючи з неї, наче пасоха з уміло прохромленого тіла... (2, с. 66), Чомувона дурна, коли вона все розуміє, знає, що і як називається, який сьогодні день, скільки яблунь вродило в Марї̈нім саду, скільки від Різдва до Різдва людей у селі родилося, а скільки вмерло?! (3, с. 5), Вона часом навіть копає посеред городу яму на глибину до своїх крижів, спускається в неї, вгортається чорним живим покривалом, що лоскоче тіло перерубаними корінцями, червами і зотлілим листям, - і так годинами чи то стоїть, чи сидить у живій землі (3, с. 13). Оскільки йдеться про інтегральну сему дії, то такі антоніми виражені дієсловами.

2. Психічні, інтелектуальні та фізіологічні характеристики людини та ї̈ стану, зокрема в реченнях: Це був часо-просторовий клубок: варто було потягти за одну ниточку, як він розмотувався до розмірів безкінечності, де люди народжсувалися, смоктали материнське молоко, пізнавали світ, їли, спали, здійснювали неймовірні махінації та гешефти, ховали свої скарби, сварилися, мирилися, гуртом захищалися від зазіхань ЖЕКу, міліції, санепідемстанції та районного відділу освіти, одружувалися, зачинали й народжували дітей і знову їли, спали, здійснювали неймовірні махінації, гешефти, ховали свої скарби, сварилися, мирилися і врешті-решт помирали... (1, с. 15-16), Вона знизувала плечима: «не знаю...» Тепер вона знає: це дім-древо, який живе в ній, підказував правильні рішення... (1, с. 157), Ніхто не хотів потопати! Усі хотіли потрапити на корабель! (1, с. 178), ... а може, ти мене просто - й не любив? Любив, я знаю, - любив, як умів: в собі, а не з себе... (2, с. 62), ...жили на цій землі якісь безіменні люди, до чогось прагнули, кохали й страждали... (2, с. 110), Вони таки не мають 
смальщю в голові а Бога в череві, їі сусіди, бо думають, що вона дурна. А Даруся не дурна - вона солодка (3, с. 5), Даруся все чує і все знає, лише ні з ким не говорить. Вони думають, що вона німа. А вона не німа. Даруся просто не хоче говорити. Слова можуть робити шкоду. Вона не знає, звідки це пам'ятає, але це правда (3, с. 15), Пропадає задурно чиясь праця, а оцей, що з гвером, - показав очима на міліціонера, - цього не видить. А Іван Цвичок мусить це видіти (3, с. 53), I добро, і лихо робили (3, с. 183).

Антоніми цієї тематичної групи переважають у творі М. Гримич, оскільки в романі йдеться про «дім-древо», розташований на вулиці Торговій, 4 у Бердичеві, - рятівну ниточку, потягнувши за яку, Ірина піднімає завісу над своїм минулим. Вона починає розуміти вчинки колишніх мешканців, тодішнє життя, що призводить до ії власного самопізнання. Такий собі лабіринт, у якому Фріда таки знаходить вихід.

Ця група антонімів широко представлена і в романі М. Матіос «Солодка Даруся», у якому описана трагічна доля родини Ілащуків. Головним прийомом створення образу Дарусі авторка обирає іiі невласне-пряме мовлення, завдяки якому читач повністю занурюється у внутрішній світ героїні. Саме через антонімічні пари, що позначають психічний стан людини, Марія Матіос передає фізичні і душевні муки Дарусі, наголошуючи на тому, що її героїня не божевільна, а перебуває у «своєму» світі.

Наявність великої кількості контрарних антонімів перегукується з широким уживання синонімів, особливо в протиставленні. Цей клас антонімів у досліджуваних творах представлений, насамперед, якісними прикметниками, співвідносними 3 ними іменниками та прислівниками, рідше займенниками та словами категорії стану, що виражають координаційні поняття. Це співвідношення здебільшого відповідає мовній нормі: - А ви чого не помогли бідній каліці раніше новим $i$ добрим? То придумайте тепер так, щоби не було видко, що воно різне і старе (3, с. 55), Бізнес, як і цей дворик, як і світове міфологічне древо, має три яруси: верхній - піднебесний, середній - земний і нижній - підземний, таємний і потойбічний (1, с. 17), Нижній ярус українського древа бізнесу - це бердичівське підземелля, яке може привести як до кляштору, тобто до святих, до раю, на небеса (мовою бізнесу - аж до верхніх ешелонів влади), або до пекла - через єврейські контрабандні тунелі до Гнилоп'яті (тобто до банкрутства) (1, с. 18), Усе періодично вмирає інаново 
народжується. Може, купити цю руїну, зробити ресторан «Фріда» і знову ожсивити дім? (1, с. 155), I лише пильне око професіонала визначило б, що їі дуже скромний і невибагливий вигляд коштує не менше, ніж шикарний Маджарянів (1, с. 170). У наведених прикладах можна виділити такі антонімічно-синонімічні ряди: cтаре - нове, добре; верхній - середній - нижній; піднебесний земний- підземний, таємний, потойбічний; рай - святі, небеса, кляштор - пекло - банкрутство; вмирати - народжуватися, оживати, шикарний - скромний, невибагливий. Лише в поодиноких випадках, зокрема у творах М. Гримич та М. Матіос, маємо синонімічно-антонімічні пари - слово літературної мови діалектизм: А нащадки такого фартового Жевуського теж грають, проте не примножують, а розтринькують набуте їхнім предком багатство, поступово убожіють, аж поки не народиться новий фартовий Жевуський (1, с. 94), - Ви, Марійо, у кого георгіни брали, що такі дуже веселі та пишні? - питає Васюта почерез паркан сусідку. - Я свої як не пильнувала, а таки якась бола їх скосила. Скрутилися, як равлики, та й по всьому. Пропали - та й по всьому. Я люблю, аби були великі і пишні квіти, а не якесь дрібнизниче, викидає оберемок айстр на стежку (3, с. 4): пильнувати - бола скосила, скрутитися, пропасти («псуватися, засихати, в'янути або зовсім гинути від надлишку чи нестачі вологи, внаслідок захворювання, від шкідників і т. ін. (про рослини)» [5, с. 1162]); великий - веселий, пишний - дрібнизничий (пор. дрібний «малий розміром, об'ємом» [5, с. 327]).

Комплементарні антоніми позначають два взаємодоповнювальні видові поняття, які разом складають певне родове поняття, без проміжних ланок. Заперечення одного з членів такого протиставлення дає значення іншого [12, с. 82].

Пари комплементарних антонімів у творах М. Гримич, О. Забужко і М. Матіос представлені

- іменниками: Ії̈ оточили хлопці. Вони не били дівчинку, тільки дражнилися, гидко сміялися, задирали догори сукню, тягали за коси, плювалися (1, с. 11), ...якби ти була мужнком, я б тобі зараз ввалив! ... Ти жінка. В цім твоя межа (2, с. 32), Дарусі здається, що бідна душа на якийсь час залишила ї̈ і полетіла на татовий голос. Лишилося одне тіло (3, с. 24), Лиш не знати, де брехня, а де правда (3, с. 122); 
- прикметниками: Древо, яке жило в ній, було бінальним: в ньому було іжіноче, й чоловіче, $i$ материнський інстинкт, $i$ батьківський, і тепло, й холод, і життя, і смерть (1, с. 173), Це вже не вперше їй кажуть, що вона не вміє любити. Але це не так. Саме вона і вміє любити, бо любить не окремо якусь істоту, до якої відчуває гормональний потяг, або з якою пов'язана материнським інстинктом, вона любить усіх однаково - $і$ хороших людей, і злих, $i$ розумних, $i$ дурних, $i$ здорових, $i$ хворих, $i$ багатих, $і$ бідних (1, с. 170), Хочу подякувати всім вам, присутнім і відсутнім, за нічим не виправдану увагу до моєї країни й моєї скромної особи (2, с. 45), - Хтозна, Варварко люба, які вони тепер: шасливі чи нещасні... хтозна... (3, с. 34), Ти хоч і дурний, вибач мені на слові, але ти часом і розумний буваєш (3, с. 57);

- дієсловами: Воно вже вмирало колись, але згодом оживало... (1, с. 153), Усе періодично вмирає і наново народжсується (1, с. 155), То скажу вам, кумко, що так ті москалі файно наших жінок просили, що легше було їм дати, як відказати (3, с. 183) (відказати «діал. відмовляти» [5, с. 170]);

- прислівниками: Я ніколи тебе не розлюблю. Пам'ятай про це завжди (1, с. 99), Воно вже вмирало колись, але згодом оживало... (1, с. 153), Народ був і лишиться таким поганим, поки йому самому не стане зовсім зле. А поки добре - народ поганий (3, с. 54), Люди добровільно побажали йти до колгоспу і починати господарювати не поодинці, а кучно (3, с. 155).

Аналіз показує, що комплементарні антоніми уживані порівняно не часто (бо їх і в мові менше), але серед них є такі, що лейтмотивом проходять через увесь твір. Наприклад, у романі «Фріда» переважають комплементарні антонімічні пари на позначення понять життя і смерті, стосунків між людьми: Так легко втратити набуте за довгі роки стримування, зрад, падінь, злетів і ще раз падінь! (1, с. 6), В обличчя війнув дивний запах, вона спершу не змогла визначити, що той запах означав - доброзичливість чи неприязнь, мир чи війну... (1, с. 22), Ірина могла програвати бої з партнерами, можновладиями, але тільки матеріально. Морально вона завжди перемагала (1, с. 25), а в творі М. Матіос «Солодка Даруся» - на позначення антагоністичних понять своїх/чужих, прихильників/зрадників, нормальних/ненормальних: ...mamu виховували чужсх дітей, як своїх... (3, с. 59), Що чудна якась та дивна - то, може, й добре: чоловіка при собі буде тримати та й сама 
свого, а не чужсого, триматися буде (3, с. 90), Що з цими людьми зробилося, що вони такі недобрі не до чужси - до своїх?! (3, с. 151), Життя і війна тривали одночасно, водночас залежні і незалежсні одне від одного (3, с. 154), Але вона не дурна, внучку, то люди думають, що вона дурна, бо не така, як усі (3, с. 184). У творі 0.Забужко простежити певну семантику комплементарних антонімів порівняно важко.

Наявність антонімів саме такої семантики зумовлено тематикою творів. Протиставлення антонімів-комплементативів створює особливу експресивність образів, побудованих на контрастах.

Широко представлені в аналізованих творах векторні антоніми, наприклад: Донизу вели сходи. Тож вона вирішила підніматися тими ж сходами вгору $(1$, с. 26), Ірина стала обережно спускатися. Тож вона вирішила підніматися тими ж сходами вгору (1, с. 26, 27), Причому жінка - це Схід, тобто почуття, а чоловік - Захід, тобто логіка (1, с. 177), Їм усім треба перемагати, от у чім справа, щиро, нелукаво брати й давати, як вуглекислота-хлорофіл-кисень, вони не вміють (2, с. 32), Спершу два кроки вліво, тоді два кроки вправо і знову вліво, і знову вправо (3, с. 88), Десь вона вже бачила на комусь таку сорочку раніше, та ні, не таку, а таки цю саму, ось на лівому рукаві верхня пелюстка удвоє ширша від нижнььӧ, мабуть, полінувалася вишивальниця перешивати заново, щоб вирівняти квітку, а на правому - пелюстки однакові (3, с. 151).

3 огляду на те, що векторні антоніми позначають дві протилежно спрямовані або взаємно зворотні дії, явища, ознаки, напрями, відношення, вони можуть бути виражені іменниками, прикметниками, дієсловами, прислівниками: Двері продлубувалися в стінах у найнеймовірніших місцях, там, де ніхто нормальний зроду їх не поставив би, і навпаки - входи-виходи замуровані там, де вони були конче потрібні (1, с. 14), Ірці завжди здавалося, що то один будинокхимера з внутрішнім двориком і виходом через арку у зовнішній світ (1, с. 14), торішні барабулі скінчилися, а на сьогорічні в Дарусі неврожай, такі дрібні, як лісові горіхи (3, с. 20), Чому тобі здавалося, ніби ти зможеш витягнути його на собі з тої ями, в яку він, очевидно ж було, так послідовно вглибав? (2, с. 38). Словник [5] не фіксує лексеми вглибати, але контекст уможливлює таке лексичне значення «заглиблюватися, занурюватися глибше». Слово вважаємо діалектною лексемою, якими насичений твір 0. Забужко. 
Як уважають дослідники, у мові за спрямуванням дій і ознак також можна виділити антоніми, пов'язані відношеннями конверсії. В аналізованих творах антоніми-конверсиви представлено менше: Першу гру Збігнєв коротунові програв... Після четвертої він знизив ставку, відповідно до грошей, що в нього лишилися, $і$ виграв (1, с. 128-129), Хочеш сказати, що в тобі нема свободи? - «Бажання вирватись - іще не свобода» $(2$, с. 87).

Наведені класифікації антонімів не можуть вважатися вичерпними Три основні різновиди антонімічних лексикосемантичних відношень можна виділити також і за іншими критеріями [1, с. 289-297], зокрема:

1. Наявність ознаки / відсутність ознаки: I це логічно. Геть нелогічним було те, що вона взяла телефонну трубку і сказала секретарці: - Нехай Петрович зайде до мене (1, с. 8), Український вибір - це вибір між небуттям і буттямм, яке вбиває (2, с. 60), Довший час звідти також важко дихала тиша - лиш було чути, як миші на горищі совгали горіхи, та під розсохлими драницями даху лопотів вітер. А далі з-за дверей почувся шурхіт, так ніби хто обдирав кукурудзяні качани... (3, с. 113).

2. Початок дії або стану / припинення дії або стану: Досьорбавши, Ірка встала, щоб піти додому, проте Берта Соломонівна жестом показала, мовляв, сиди. Та слухняно сіла на стілещь (1, с. 12), Вирубала в собі всі застережні табло, і тільки вірші, що негайно ввімкнулися натомість $і$ пішли суцільним, нерозчленованим потоком, пропускали недвозначні сигнали небезпеки (2, с. 42), Отож, з того часу широким гребенем дамби можна було не тільки йти, але навіть бігти (3, с. 104). Пару слів з тексту 0. Забужко вмикати вирубати уналежнюємо до антонімів на підставі семантики останнього слова «розм. Діючи рубильником або вимикачем, припинити надходження електричної енергії, перервати дію електричного механізму; вимкнути» [5, с. 149]. Наведений приклад можна розглядати і як контекстуальні антоніми, бо слово вирубити належить до іншого функційного стилю, ніж нейтральне вмикати.

3. Більший ступінь вияву ознаки / менша кількість або ступінь ознаки (тип «більше - менше»): Вона спрагло, немов губка воду, вбирала в себе велику й малу науку ведення бізнесу в Україні, а паралельно ще й риси його вдачі та звички (1, с. 9), Я не лише не кращий від «усіх тих Жевуських», я гірший за всіх них! (1, с. 93), «Чого зараз - великі? - сміявся очима, й вона відтавала усміхом йому 
назустріч: - Може, ж, якраз і мишачі - невеличкі такі? (2, с. 58), Нас уже не так багато, але ще й не мало (3, с. 163), Але це таки правда, що нікому так не є погано, як нашим ворогам, коли нам добре (3, с. 69).

Антоніми можна класифікувати й за іншими семантичними принципами. Визначаючи зміст ознаки, за якою протиставляються значення слів, до уваги беруть такі показники [12, с. 151]:

1. Орієнтація в часі й просторі: 3 двох варіантів - опинитися на даху будівлі чи в підземеллі - вона вибрала перший (1, с. 27), Хрестіться, дітво, рано і увечір хрестіться, та просіть Бога, аби вас обминула така тяжка судьба (3, с. 181).

2. Колір та його відтінки: Фріда сказала, що зустріла там якогось чорнявого чоловіка з білосніжнною бородою $i$ золотим зубом (1, с. 28), Навіщо Вам, світлій, осяйній, сонячній душі, демон темного царства? (1, с. 94), «Авжеж, зліпи собі, серце, голову, зліпи - не завадить!» - він темнів на виду так, ніби замість крові влиця вдаряло чорнило (2, с. 21), Мокрі ліхтарі вдрібноголчастій сріберній облямівці, й чорний маслянистий блиск зустрічних калюж, - все злилося, навально помчало навперейми, забиваючи дух (2, с. 34), Його невідривно звернене до тебе промінно-заворожене обличчя осявало ще тьмяну майстерню (2, с. 41), Білі - неначе вовняні - сніги лежали від верхів до низу непорушним саваном, прошиті хіба що лиш чорними піками смерекових і букових лісів, та вирвані латками теплих осель, над якими вився пахучий дим (3, с. 107).

3. Смакові відчуття: Марія думає, що ї повидло солодке. Ніяке воно не солодке - терпке, язик і ясна пощипує (3, с. 19). Така антонімічна пара виявилася одиничною серед досліджуваного фактичного матеріалу.

4. Стать: - ...Ірко, ти що, з Гуйви втекла? - кричала на неї матір. А батько не кричав (1, с. 11), Так вони й дотанцювали той божевільний танець - лише удвох: молодий, що діставав головою мало не до неба, і молода, малопритомна від незвички, сорому і того, що ї̈ чекало за брамою нового життя, в чужому селі, без татамами - лише в Господній і ї чоловіка волі (3, с. 86), Жінка, що має чоловіка, - то не дівка, що вона розплітала косу, а Михайло, вповідали старі люде, чесав їі, як дитину (3, с. 182).

5. Можливість, ймовірність / неможливість, нездійсненність дії: «A де шиють такі платтячка?» - «Ніде не шиють, - сумно посміхнулася тітка Ірена (1, с. 37), Досить глухо, але ж Ірка їх чула. А от Андрій не чув. Чи просто вдавав, що не чує... (1, с. 45), Ти маєи рацію, мені не 
потрібна пара... Я сама собі, сама по собі і сама собою... - Може, ти помиляєися? Може, тобі потрібна не абсолютна самотність (1, с. 175), А коли вже по великій правді, то, як на те пішло, нічого ці двоє не хотіли... хіба що хотіли бути окремішними від усього (3, с. 124), Усі там у світах смерть свою познаходили, а кому й вертатися не можна було, а вже як було можна - то не було кому (3, с. 182). Як бачимо, такі семантичні відношення виражено найчастіше через антонімічне дієслово із заперечною часткою не.

Отже, семантична класифікація грунтується на відмінності між різновидами протилежності - контрарної та комплементарної. В аналізованих творах спостережено як градуальні, так і комплементарні та векторні антоніми.

\section{Структурна організація антонімів у творах М. Гримич, 0. Забужко, М. Матіос}

За структурою антоніми поділяють на однокореневі та різнокореневі. Однокореневі антоніми можна охарактеризувати як лексико-граматичні, або, точніше, словотвірні, тому що формування їх здійснюється за безпосередньою участю словотвірних засобів, здатних виражати протилежні значення відповідних похідних лексичних одиниць [12, с. 153].

В аналізованих творах виділено такі однокореневі антонімічні пари: В кухні - крихітній еat-in kitchen холодильник, електроплитка, шафки з абияк учепленими дверцятами, що наврипились, іно відвернешся, безсило відхилятися, як щелепа на вженесамовладному обличчі (2, с. 17), Ії̈ пальці колишньої гітаристки набули невідмивно-жовтяничного кольору й насилу розгиналися (2, с. 88), «Хелло!» - десь далеко на безмовній лінії свистав шугастий вітер і глухо рокотав океан (2, с. 33), І стояв у тісному, як ліфт, передпокоїку, зі схрещеними на грудях руками, підпираючи двері, покотячи вимовно світячи в неї очима (2, с. 81), - Аби то лише на добре, аби на добре... - чи то осудливо, чи співчутливо кивали головами старі жінки і молодиці на лавах попід стінами весільної хати, ніби дивилися в якусь відкриту лише для них, але невидиму для решти, книгу долі, а може, лише видобували зі скринь власного досвіду безпомильні знання про майбутнє двох молодих $і$ глухих у своєму щасті людей, що поволі приходили до тями після «гуцулки» (3, с. 86), То скажу, тобі, Міську, що навіть я, коли був солдатом, задурно так не бігав та порохи не збивав дорогою, пужаючи псів, як 
ці тепер шурують від дзвіниці до жандармерії, ніби їм помилилося в голові (3, с. 117).

Аналіз фактичного матеріалу з романів М. Гримич, О. Забужко, М. Матіос уможливлює висновок про те, у творах названих письменниць переважають однокореневі антоніми з префіксом без: Але ж радянська влада справедлива: для неї всі рівні (3, с. 72), І дехто з місцевих газдів у цьому безчассі і тимчасовому черговому безвладді встиг навіть поживитися залишеним майном (3, с. 149), особливо в 0. Забужко: Тимчасом у ї кембриджській хаті, знай перемірюваній безтямною ступою з кутка в куток - від вхідних дверей через кімнату до кухні й назад - щось незбагненне койлося $з$ телефоном (2, с. 33), Оттоді-то було й втямити, що дім твій мова (2, с. 27), Ти наповажилась була воздвигнути на стоякові імпровізований зимовий сад із двох безневинних вазонів (2, с. 18), Все, що нам дано - то готові порізнені скалочки дійсності, фрагменти, подробиці, кольорові фішки якоїсь великої, неосяжної головоломки, по яких рачкуємо, не підводячи зору, обмацуємо, облизуємо, обнюхуюмо собі в кайф, цілком безневинне й приємне заняття (2, с. 144), Бо я винувата-таки, бо любов моя зосталася в Кембріджі, станула по весні з глибокими снігами (2, с. 107).

Поодинокими $є$ антонімічні пари зі структурою антонім + антонім із префіксоїдом, зокрема Адже, попри всі гріхи, «осоружний» рід Жевуських завжди відзначався шляхетністю, справжнньою шляхетністю, а не манірною псевдошляхетністю інших, добре відомих Вам родів (1, с. 92). В аналізованому прикладі зіставлення посилено ще й антонімічними прикметниками справжній - манірний.

На окрему увагу заслуговують «найпримітивніші» антоніми $[10$, с. 95], утворювані заперечною часткою не- здебільшого в префіксальній функції. У частині випадків вона виражає значення відсутності тієї або тієї ознаки, унаслідок чого в антонімічній парі виникає відношення повної протилежності [12, с. 153], наприклад: Дивна річ, думала Ірина, дивна психологія радянського обивателя: престижно було вдягатися в ті самі кофтинки, костюмчики, блузки, що й окремі місцеві авторитети - офіційній неофіційні (1, с. 36), Завелася мурашва, бо по стільниці раз у раз повзе щось, що в гігієнічному американському домі не повинно би повзати, та $і$ в неамериканському теж (2, с. 17), "Бо це успадковується», - «Ні чорта не успадковується - хочеш сказати, що в тобі нема свободи?» - «Бажання вирватись - іще не свобода» (2, с. 87), Але після тої ночі 
знав найголовніше: Дарусю можна вилікувати. Як-Іван не знав, але знав точно, що можна (3, с. 68), ...Життя і війна тривали одночасно, водночас залежні і незалежні одне від одного (3, с. 154).

Кількісний аналіз фактичного матеріалу, підтверджує поширену в мовознавстві думку про те, що серед різнокореневих антонімів найчастіше спостерігаються прикметники ((Бізнес, як $і$ цей дворик, як і світове міфологічне древо, має три яруси: верхній - піднебесний, середній - земний і нижній - підземний, таємний і потойбічний (1, с. 17), Зараз у нього роботи багато - народ шиє нове, перешиває старе, тож Мойсей Давидович без копійки не сидить, бо справу свою знає, тим паче, він майстер верхнього одягу, а таких тепер бракує (1, с. 103), Я вчилася науки розставань: Науки розрізняти біль недужний I біль животворящий (2, с. 28), Аж тут з цвинтарної брами виходить солодка Даруся і така якась чудна та дивна, і така похожа на оту мару, що я, кажу вам правду, Марійо, уже й не зрозуміла ні дві-ні три: хто з нас дурний, а хто розумний (3, с. 30), То що - вони такі мудрі, а я - дурніша? (3, с. 133), , потім іменники (Я хочу бачити тебе завжди - у радощах і смутку, в розкоші й злиднях! (1, с. 95), ...навіть якби всякі там невдахи витикали вам нею очі, дурниця то все, щиро кажу, - злуда, омана: тільки в дитинстві є правда, тільки ним і варт міряти своє життя (2, с. 84), Це була якась дика гортанна безвихідь $і$ надія водночас, подяка $i$ прохання, прокльон і сміх... (3, с. 68) і дієслова (Це ти розкриваєшся - або закриваєшся: як у цьому випадку - намертво (2, с. 24), Мабуть, той, хто першим поклав почуту в собі мелодію на струни, зазнав усього, що може зазнати чутлива в житті людина, бо укладав ті звуки в ритм, яку пазуху: і тішився, і плакав, чи, може, тільки схлипував після купелю в них... чи скрикував, як в очищувальній воді морозного потоку (3, с. 87), однокореневі антоніми наявні серед усіх лексико-граматичних розрядів слів, а найбільш частотними є дієслівні антоніми (Ну, то й що, що коріння жоржин загортала в ковдру? (3, с. 5), Даруся викладає з кошика припасене добро довкруг хреста, розгортає з марлечки сир, масло, відщипує пучечком по маленькій дрібочці, кидає в рот (3, с. 27), Даруся два дні не виходила з хати - так ї̈ боліла голова, що не могла дивитися навіть у стелю, лиш обв'язувалася хустками, накривалася подушкою і відверталася до стіни (3, с. 8), Як падуть холоди, заходить у воду лиш до колін (3, с. 9), Дідушенко різко розвернувся до нього (3, с. 156), оскільки ця частина мови відзначається 
багатством антонімічних префіксів [11, с. 83], у нашому випадку роз-/за-, ви-/за-, від-/роз-, ви-/за-, в-/ви-).

Отже, за структурою антоніми бувають однокореневі та різнокореневі. Як свідчить фактичний матеріал, серед однокореневих переважають дієслова з різними антонімічними префіксами, а серед різнокореневих - прикметники.

\section{Частиномовна та рівнева належність антонімів ухудожніх творах}

Явище антонімії дослідники спостерігають на різних мовних рівнях, отже, виділяють щонайменше лексичні та фразеологічні антоніми. Серед одиниць фактичного матеріалу виділено лише один приклад фразеологічних антонімів: - Семакіних уже й слід прохолов! Він одразу ж по тому, як пропав Рубік, переїхав до Києва. Шукай вітра в полі! - Я його з-під землі знайду! - скреготав зубами Рафік (1, с. 31). Уважаємо це фразеологічними антонімами через те, що це фразеологізми 3 протилежним значенням, яскраво виявленим у контексті роману, пор.: шукати (ловити, доганяти) вітра в полі «здійснювати безрезультатні пошуки кого-, чогонебудь» 1 - діставати (добувати, видирати) з-під землі «робити щонебудь неймовірне; досягати чогось майже неможливого; здійснювати що-небудь будь-якими засобами». Семантику першого (з позитивним значенням) фразеологізму поглиблює синонімічна до нього фразеологічна одиниця слід прохолов («хто-небудь утік, безслідно зник»).

Фактичний матеріал, дібраний із творів письменниць, дає підстави висновковувати про те, що лексичні антонімічні ряди представлено такими частинами мови:

- іменниками: Вони наживали перші капітали на різноманітних махінаціях, на грі на межі закону й криміналу, на «золотій лихоманці» (1, с. 180), Ми відкриваємось йому так само, як у мить народження або смерти, - і ти вирвешся, о, вірю, знаю! (2, с. 114), Добре, якщо літо і вода тепла. Тоді ніхто не боронить ставати у воду. Як падуть холоди, заходить у воду лиш до колін (3, с. 9);

- прикметниками: Життя перетворюється на фантасмагоричну мішанину реальних і нереальних подій, соціалістичної

1 Значення фразеологізмів наведено за: Словник фразеологізмів української мови / уклад. В. М. Білоноженко та ін. Київ: Наук. думка, 2003. С. 780, 206, 663 (відповідно). 
дійсності і дореволюційних устоїв (1, с. 118), Виявляється, ті стреси, що їх завдавали їй люди чи ї справа, були маленькими репетиціями великого шоку (1, с. 148), Щойно звареного гарячого варення з «городською» свіжою булочкою і холодною сирою водою, щойно накачаною з колонки (1, с. 166), Мова, дарма що незрозуміла, на очах у публіки стяглася довкола тебе в прозору, мінливоряхтючу, немов із рідкого шкла виплавлювану, кулю, всередині якої, це вони бачили, чинилась якась ворожба (2, с. 27), Світ зробився непрозорим, вимкнулось і погасло його друге дно (2, с. 105), Прокляте - не прокляте, а що місце моторошне, - то правда (3, с. 105), Що то є молодий розум! Молоде - дурне. А старшого слухати не хоче (3, с. 120);

- займенниками: Яка сила привела ї̈ сюди? Хто примусив ї̈ порпатися в минулому - своєму i не своєму? (1, с. 150), «I не подумаю. Це - моє», - твоє, голубе мій, іно те, що намалював, і не треба себе дурити: в що сам не провалюєшся - на безбач, з головою ніколи твоїм не стане (2, с. 61), - А хто зробить не по-моєму, сам буде у ставу жабів ловити! Два дні плавало порося у воді, та ніхто із Славкових домашніх не зглянувся над умертвленою душкою, боячись п'яного вар'ятського характеру господаря (3, с. 7), Господи милосердний... у бездітної Калинички було стільки своєї одежі, що стачило би на три дівки-відданиці. То нащо їй чужі сорочки $i$ запаски? (3, с. 151);

- дієсловами: Як зненацька з'явився я у Вашому житті, так і зникну з нього - раптово і безслідно $(1$, с. 92), Я хочу бачити тебе щодня, коли прокидатимусь і коли засинатиму! (1, с. 95), Фріда померла. Фріда воскресла $(1$, с. 183), А може, ти мене просто - й не любив? Любив, я знаю, - любив, як умів: в собі, а не з себе... (2, с. 62), ...А Солодка Даруся сидить у квітнику між айстрами, у трьох кроках від Марії з Василиною, заплітає-розплітає давно поріділу сиву косу, слухає незлобну розмову про себе, і лиш тихо усміхається (3, с. 5), Там то на Україні який голод був, а вони нам про це сказали? Не сказали (3, с. 118);

- прислівниками: Уранці йдеш, чайку сьорбнувши, а ввечері -ледь ноги доволочиш, і на койку! (1, с. 108), «Мені ж потрібна партнерка на цьогорічному Віденському балі - чи то серйозно, чи то жартома сказав Маджарян» (1, с. 171), А якщо мені зараз сподобається тебе підпалити, що тоді? (2, с. 25), Жодне з тих, більш або менш талановито виписаних і оправлених у фоліанти з постинаними корінцями чужих життів, жодне з тих життів не має до неї 
стосунку (2, с. 95), Хоч узимі, хоч уліті (3, с. 39), Він ще й дримби робить з таким завзяттям, як нормальні люди уліті роблять сіно чи взимку - дітей (3, с. 72);

- прийменниками: Можна також подавати який-небудь джус чи джин з тоніком у високих товстобоких шклянках, можна з льодом, можна й без льоду (2, с. 17), ...куди ти зійшла з естради, відчитавши своє - два вірші, два холєрно добрі вірші просто в нетверезий гул злитих в одне довкружне блимання жовтоплямних фізій, точніше, поверх нього... (2, с. 26), А може, ти мене просто - й не любив? Любив, я знаю, любив, як умів: в собі, а не з себе... (2, с. 62), "Бо до шлюбу вона княжна», - відповів тато. "А після шлюбу? - питала Даруся (3, с. 22).

Отже, антоніми в досліджуваних творах представлено здебільшого прикметниками та дієсловами. Зважаючи на категоріальне значення, антонімічні прикметники увиразнюють порівняння, створюють контрастні картини, дієслова ословлюють дію, іменники - предметність.

\section{Особливості оказіональних антонімічних пар досліджуваних романах}

За протилежністю значень у лексичній системі мови виділяють передусім загальномовні, або узуальні, антоніми. Їм властиві істотно важливі ознаки, а саме: 1) стійке лексико-семантичне відношення в межах відповідних пар слів, унаслідок чого вони постійно взаємодіють у словниковому складі як парадигматично взаємозумовлювані одиниці; 2) регулярна відтворюваність у тих самих синтагматичних і стилістичних умовах [12, с. 154]: Ти і є така істота - в тобі існує разом чоловіче і жіноче (1, с. 173), Леді й джентльмени - ні, наразу тільки леді, точніше, одні леді (2, с. 162), Прийміть вітання і од мільйонів убивць по всіх тюрмах світу, і десятків мільйонів, що ходять на волі (2, с. 166), Добре, якщо літо і вода тепла. I чим холодніша вода, тим швидше біль відпускає Дарусю (3, с. 9).

До сфери антонімічних відношень потрапляють слова, причому не обов'язково належні до одного лексико-граматичного класу, за принципом оказіонального, характерного для відповідного конкретного контексту протиставлення значень, виразної антитези [12, с. 155], наприклад: Ти наповажилась була воздвигнути на стоякові імпровізований зимовий сад із двох безневинних вазонів, то були: пишна темнозелена кучма в жовтогарячих квітах - раз, $i$ рясне намисто лискучих, схожих на пластикові, червоних бубок на високих стеблах з елегантно завуженим листям - два; зараз обидва 
вазони мають такий вигляд, ніби ці три тижні їх день у день поливалося сірчаною кислотою, - на місці буйної кучми клаповухо звисають кілька пожсовклих листочків з нерівно обгорілими краями, а колишні тугі червоні намистини щодалі, то більше нагадують сушену шипшину, навіщось поначіплювану на руді цурпалки. Подлі американські бур'яни виявилися заніжні на твою депресію, взяли й здохли, поливай не поливай (2, с. 18), Розумом запевняла себе, зціпивши зуби: хай хоч гірше, аби інше! - а вірші обіцяли: «Цієї ночі, певно, прийде жах. Моя беззахисність така тепер зовсюдна, Немов одвертий заклик злу: Приходь!» (2, с. 102), як антитеза раціонального, логічного і душевного, емоційного.

Стилетвірною ознакою ідіолекту Марини Гримич постають контекстуальні антоніми-іменники: Гра - це не просто моя забаганка. Це моє покликання, моє прокляття, мій обов'язок перед фамілією (1, с. 94), Але з облич присутніх збагнув, що це в міській міліції я герой, а тут - пішак (1, с. 122), - Не знаю, здається, краще в раю... - Ні, дитинко, краще на землі $(1$, с. 174), - Перегорни кілька сторінок назад і подивись, які тут Адам і Єва. Еге ж. Ти правильно сказала. Як ляльки. А на землі вони - люди (1, с. 175).

Цікавими в романі $€$ і прикметники, поєднувані контрастним часовим значенням: У міфологічні часи героя з лабіринтів виводила нитка Аріадни або клубочок, що котиться сам а в постіндустріальному суспільстві роль провідника у ворожому просторі виконує мобільний телефбон. Кумедно (1, с.67). Також виділено контекстуальні дієслівні: Ти покинув мене саму виплутуватися. I я виборсувалася сама, як могла $(1$, с. 146) та займенникові антоніми: Тu i $\epsilon$ така істота - в тобі існує разом чоловіче $і$ жіноче. Ти сама собі, сама по собі, $i$ сама в собі одночасно $(1$, с. 173$)$.

Особливістю тексту «Солодкої Дарусі» М. Матіос уважаємо прикметникові контекстуальні антоніми: $A$ Даруся не дурна - вона солодка (3, с. 5), - Люди з писанками до наромальних (нормальних) людей ходять, а солодка Даруся останнє яблуко принесла чорному n'яниці (3, с. 13), Подивіться лишень на цих двох нещасних, - киває почерез паркан у сусідський двір. - Голову до голови притулили та й німують обоє, і на наромальних людей не зважають (3, с. 34), Хіба наромальна людина буде отако сидіти посеред білого дня і слухати, як дурний у дримбу грає? (3, с. 34). Переважання антонімів такої семантики та частиномовної належності пояснюємо тематикою 
роману: йдеться про іншість, інакшість Дарусі Ілащук, нетрадиційність її поведінки: Люди в селі часом роблять таке, що навіть Даруся хапається за голову, але їх дурними чомусь ніхто не називає, а про неї, що говорить з деревами і квітами, і живе собі, як хоче, хоч і шкоди не робить нікому, думають, як про дурну (3, с. 6), Але вона не дурна, внучку, то люди думають, що вона дурна, бо не така, як усі (3, с. 184). Закінчується роман філософськими роздумами про мінливість людського життя, побудованими також на антонімічності прикметників на позначення кольору: Життя то трояка ружа. ... Ти думаєш, що ружа ружевий колір має. А воно ні. На то вона трояка ся називає. Так $і$ життя. То чорне тобі покажеться, то жсоте, а там, дивися, загориться червоним. Ніколи не знаєш, яку барву завтра уздриш. Чекаєш одної, а воно тобі показує другу (3, с. 185).

Смислове перетворення слів Оксана Забужко використовує залежно від змісту тексту, простежити закономірності семантичного вживання контекстуальних антонімів в їі творі важко. Утім, такий вид антонімів представлено і в аналізованому романі: ...щось жило, пульсувало, випростувалось, розверзалось провалами, набігало вогнями - й знов затуманювалось, як $i$ належить шклу од за близького дихання (2, с. 27), Все, ходім звідси, і раптом різко гальмував на місці, закидаючи голову назад, з мукою невтоленної жаги вхлипуючи повітря (2, с. 70), Півупаковки транквілізаторів плюс бритва, - і вибачте за невдалий дебют. Старалася щиро, на совість, а що ні фіга не вийшло, то чесніше одразу здати карти - не гравець із мене й зараз (2, с. 19). В останньому прикладі антонімічну пару складає слово літературної мови старатися та синонімічні жаргонні вирази нi фіга не вийшло та здати карти. Зауважимо, що уживання позанормативної лексики - особливість лексичної системи цього твору 0. Забужко (лотра, замахали, прибамбаси, шмаровило, мать його за лапу... тощо).

Отже, контекстуальні антоніми $є$ ознакою індивідуального стилю кожної письменниці, вони виявляють підкреслено емоційне бачення явищ дійсності художником слова, який мислить і оцінює їх крізь призму своїх почуттів, свого темпераменту. 


\section{Стилістичні функції антонімів}

\section{у романах М. Гримич, О. Забужко та М. Матіос}

Антонімічні відношення пов'язують зі стилістичними функціями, що їх виконують слова-антоніми в певному контексті. Зображальні функції антонімів у творах М. Гримич, О. Забужко та М. Матіос дають змогу виразити в мові найрізноманітніші семантичні відношення, а саме: диз'юнкцію, кон'юнкцію, зіставлення, взаємне перетворення протилежностей, суперечність (застосовуємо класифікацію В. А. Василенко) [4, с. 9].

Найпоширенішу групу становлять антонімічні опозиції, що виражають семантичні відношення протилежності зі значенням диз'юнкції (у мовознавстві - відмінність, протиставлення, різниця [5, c. 294]. Це логічна операція, що полягає у з'єднанні двох чи більше висловлень у нове, складне судження: Ірина могла програвати бої з партнерами, можновладиями, але тільки матеріально. Морально вона завжди перемагала (1, с. 25), Розі - сорокарічна дівчинка, мати дорослої дочки, і така ж маленька, худенька, як горобчик, незмінно чи то перестуджена, чи перегріта на сонці, чи принаймні перевтомлена - змушена підшукувати собі якусь пращю (2, с. 69), Так вони й почеберяли: Даруся з кошем попереду, Може, краще б ніколи не йти до танщю під цю сумну, як жіноча доля, і безконечно гостру, немов неминуче занесена сокира історії над кожною чоловічою головою, мелодію; може, краще стояти осторонь, підперши напруженим тілом паркан чи дерево, і просто слухати, і думати; може, краще ніколи не брати той навіки заданий $і$ незмінний за жодних умов ритм: два кроки вліво, два вправо... (3, с. 89).

Кон'юнкція (спосіб об'єднання двох чи більше висловлень в одне ціле за допомогою сполучника $\boldsymbol{i}[5$, с. 571]) спостерігається, коли антонімічні пари постають як антонімічні єдності: ...так, саме так, братіку, не можна, це тайна, твоя і моя, - печать на вуста, як сухий цілунок: замкнути, мовчок, мовчок (2, с. 65), А приймати як $е$ якпогоду й негоду (2, с. 100), Твоя власна мука, на мить осяяна пізнім, навзахіднім проблиском смислу, - не одинока, не перша й не остання... (2, с. 110). В аналізованих творах виявлено лише поодинокі приклади кон'юнкції на підставі антонімічних відношень.

Функцію протиставлення, що полягає у вживанні антонімів для розмежування понять i реалій за семантичними ознаками, простежено і в реченнях: Ось і прибув я в Бердичів - містечко таке на Україні. Тільки українців тут живе небагато. Все більше в селах, а 
в самому містечку - переважно поляки та євреї (1, с. 101-102), Вкладеш зерно і працю в землю - вона почне родити, не вкладеш не отримаєш урожай (1, с. 162), Ми-бо все чекали свого весілля, вишивали собі пісень, хрестиком, слово до слова, і так упродовж всенької історії, - ну от і довишивалися (2, с. 100), Особливо, коли парубок бере сторонську, а не свою, сільську, дівку і роззирає її вночі і вдень з усіх боків, як писанку, писану в чужому селі (3, с. 83), Огронник сидів уже кілька місяців, та до сьогодні село знало, що сина він не продав. Певно, продав хтось інший, якщо мертвий тепер Іван nідпирав сільраду (3, с. 159). Інколи таке протиставлення в тексті викликає різкий злам у його семантичній структурі, виділений автором графічно (курсив додано 0. Забужко): Виживання, скоро підміняє собою життя, обертається виродженням (2, с. 100).

Особливим виявом експресивної ознаки позначено моделі, що реалізують контрастне антонімічне зіставлення: Діти несуть залізо, як на приймальний пункт, а Цвичок голосно розпоряджається: коротке залізо - під стіну, довгі труби - в хату, гайки-цвики - у плетений кіш $(3$, с. 47). Зіставляючи протилежні за значенням поняття, виражені словосполученнями, письменник посилює контраст, чим i викликає співчутливе ставлення до персонажа: Боя, дурень, вірив, що моя стражденна душа, вічна мандрівниця в цьому лабіринтоподібному та буремному океані життя, може знайти тиху гавань біля іншої душі, чистої $і$ не затьмареної міцанством чи пихою! (1, с.91), Скільки мені відходити від тебе, скільки тобі - від мене? (2, с. 38), Далі слухати такий колоритний бригадирчин монолог міг тільки хіба що дерев'яний чоловік. А Цвичок був чоловіком живим, отож він сміливо посунув на Ірину з вилами (3, с. 49), Люди, може, й забули. Але Бог усе видить $і$ все пам'ятає (3, с. 183). Контрастне зіставлення може увиразнювати, поглиблювати психологічний ефект від зображуваної картини: Але ж Гермес - не надгробок на цвинтарі, $a$ живий чоловік! (1, с. 88), Вона лежить, обліплена мухами, на зогнилих від часу дерев'яних сходах, у діамантах, костюмі за п'ять тисяч баксів; ї̈ білосніжна білизна промокла коричневим від жовчі потом; під наманікюрені нігті забилася чорна стара пилюка. Конкуренти не казатимуть про неї «померла», «загинула», про неї скажуть: «здохла!..» (1, с. 147), Ніколи не знаєш, яку барву завтра уздриш. Чекаєш одної, а воно (життя) тобі показує другу (3, с. 185). 
Антоніми, порівнюючи різні реалї та поняття, виконують функцію зіставлення, наприклад, і в таких реченнях: Берта Соломонівна варила (повидло) довго, аби не «забурділо», і розливала його в трилітрові банки. Пані Ірена варила варення кілька разів короткими заходами, навіть не доводячи його до кипіння, розливала в маленькі баночки, переважно майонезні, і зберігала в підвалі. А тітка Аня Соболєва любила все «брати під кришку» вона не мала терпіння ні пані Ірени, ані Берти Соломонівни. «Знову зірвалося, падло!» - так само весело казала вона, виливаючи своє вариво у помийне відро... (1, с. 166), Як жити, терпіти, не згадувати, перед людьми не соромитися, прощати навмисне $i$ ненавмисне зло (3, с. 31), Функція зіставлення найяскравіше виявлена для антонімів роману М. Гримич «Фріда». На нашу думку, це можна пояснити тематикою роману: показати, довести дієвість триярусної будові світу і Всесвіту (і бізнесу для героїні твору ІриниФріди): Це був не будинок. Це було міфологічне світове древо 3 трьома ярусами - піднебесним, земним і підземним. На верхньому ярусі жили його святі - кушнір Мойсей Давидович, Рафік Варданян - директор Бердичівського ринку, Берта Соломонівна відома в широких торгівельних колах Бердичева, Бессарабки й Подолу комісіонщиця, Жевуські - люди хоч і без певного роду занять, проте дуже заможні й авторитетні. На земному ярусі мешкали земні люди - військово-освітянсько-чиновнццькі різночинці Соболєви, Альперовичі й Ковалі, а також коти, собаки і таргани. А підземний ярус був найтаємничішим, найзагадковішим. До нього належали ... кілька напівпідвальних кімнаток, куди періодично вселялися і звідки так само періодично зникали всі бердичівські маргінали - жебраки справжні, жебраки-симулянти, крадії, лжепророки тощо. Це була модель їі світу. Зрештою, її бізнесу. Бізнес, як і цей дворик, як і світове міфологічне древо, має три яруси: верхній - піднебесний, середній - земний $i$ нижній - підземний, таємний і потойбічний. Нагорі сидять бізнес-святі (несуттєво, як їх звуть - Мойсеями Давидовичами, Бертами Соломонівними, Маджарянами чи Іринами Ревуцькими). На середньому рівні вештаються земні істоти - діти, люди поза бізнесом, коти, собаки, собакоподібні люди ілюдиноподібні коти, дорослі люди $і$ вічні старигани. А ось нижній ярус - це найбільш незрозумілий $i$ небезпечний світ. До нього ведуть центральний вхід і чорний вхід. Центральний вхід для невтаємничених - міліціонерів, податкової, 
санстанції, мас-медіа, обивателів. А справжній вхід до нижнього ярусу завжди таємний. Він схований у найнесподіванішому місиі, зручному для бізнес-святих, тобто тих, хто перебуває на верхньому ярусі. Лише небожителі мають доступ до чорного входу, до таємного підземного світу бізнесу - темного, лабіринтоподібного, небезпечного, із замурованими скарбами та кістками людей, що згинули в бізнесі $(1$, с. $15,17-18)$.

Концептуально навантаженими $\epsilon$ антоніми, що вступають у тексті в семантичні відношення взаємного перетворення протилежностей, наприклад: Воно вже вмирало колись, але згодом ожсвало... (1, с. 153), Усе періодично вмирає $i$ наново народжсується $(1$, с. 155$)$.

Семантичні відношення суперечності, тобто з'єднання протилежних начал, базуються в письменниць на оцінному характері семантики антонімів, наприклад: $B$ обличчя війнув дивний запах, вона спершу не змогла визначити, що той запах означав - доброзичливість чи неприязнь, мир чи війну (1, с. 22), Тоді-то й стало зринати промельком, скидом, вихопиться й спорсне - відчуття якоїсь наскрізної відкритості-всім-вітрам: на добре чи на зле? (2, с. 102), Але чи правду казали, чи таки брехали, хто знає? (3, с. 110).

Загальновідомо, що основна функція антонімів - бути лексичним засобом вираження антитези. Різке протиставлення понять дає змогу авторові створити виразний, об’ємний образ: Оце древо Торгової, 4 мало не суворо симетричну форму, як в орнаментах народів світу, а було потворою, химерою: стовбур (тобто центральний хід) роздвоювався, а може, навіть розтроювався, щоб уже нагорі сплестися в одну крону (цілісність усіх мешканців дому-химери), його гілки (чорні ходи) переплелися в дивний вузол, розібратися в якому могли лише мешканці певної частини будинку, акоріння (тобто підвальні йнапівпідвальні приміщення, підземні ходи) було найбільш заплутаною частиною дому: один корінь ішов глибоко вниз, у невідомому напрямку, а точніше, в невідомість, у вічність. Другий корінь був підтятий (прохід завалено або замуровано), третій корінчик, на перший погляд, згнив, однак то тільки здавалося, а натреноване око мешканця дому-химери бачило, як біля гнилого й безнадійно хворого відростку (одного тунелю) тягнеться цілковито здоровий корінець (інший тунель), і тягнеться він до тієї самої невідомості, ба навіть вічності (1, с. 15-16). За допомогою антитези М. Гримич увиразнює картини, у яких зіставляються прямі й переносні 
значення слів: симетрична форма - потвора, химера, ословлюється різке й несподіване зіткнення різнорідних понять: стовбур (центральний хід) - гілки (чорні ходи) - коріння (підвальні й напівпідвальні приміщення, підземні ходи); Вона сподівалася побачити там великий дерев'яний стіл, за яким сиділи старі мешканці міфологічного дому-древа і грали в карти, але натомість застала дику пустку (1, с. 17); Ці - в одностроях і з автоматами, як прочісували арабські йхристиянські квартали, посуваючись по осонню з облудно лінькуватою грацією ситих хижаків, - могли бути нащадками Авраама i Якова, мій же професор - вже самими отими мерзлякувато, чи то вибачливо, скуленими (укритися, сховатися, догідливо підхихикнути й злитися з меблею) плічками заперечував достеменність Старого Заповіту: з такими плічками неможливо боротися з янголом, взагалі нічого неможливо, окрім як бігти «по вєрьовочкє» (2, с. 101-102) (Авраам і Яків - біблійні персонажі, родоначальники багатьох народів, зовні й духовно красиві людини).

В аналізованих творах антитезу виокремлюємо як в межах одного речення: - Аби то лише на добре, аби на добре... - чи то осудливо, чи співчутливо кивали головами старі жінки $і$ молодиці на лавах попід стінами весільної хати, ніби дивилися в якусь відкриту лише для них, але невидиму для решти, книгу долі, а може, лише видобували зі скринь власного досвіду безпомильні знання про майбутнє двох молодих і глухих у своєму щасті людей, що поволі приходили до тями після «гуцулки» $(3$, с. 86), так і цілий твір може бути побудований на цьому художньо-зображальному прийомі: Пустка оглушила й осліпила ї. Дім був геть порожнім. Міфологічного дому-древа не було. Була руїна. Вона сиділа приголомшена і спустошена ... Відчула, як у неї всередині ожсває древо, як розгортаються прив'ялі листочки $i$ набрякають бруньки, як у стовбурі починають пульсувати соки... Ось воно, древо, розгортає гілки, $і$ ось розпукуються бруньки, з яких вилазять липкі квітки, азних пізніше народяться плоди (1, с. 17,182); Але подлі американські бур'яни виявилися заніжні на твою депресію, що незбовтана гусне в цих чотирьох стінах, взяли й здохли, поливай не поливай, - а ти ще хочеш, щоб тебе держалися люди!) ... А чому б не тепер?... Не вже?... Чого чекати?... Логічно зваживши - нічого. Геть-таки зовсім. Півупаковки транквілізаторів плюс бритва, - і вибачте за невдалий дебют. ... В юності я мріяла про таку смерть: авіакатастрофа над Атлантикою, 
літак, що розчиняється в небі й морі, - ні могили, ні сліда. Тепер я всім серцем бажаю цьому літаку щасливого приземлення: мені подобається дивитись на високого, жилавого старого, і на іспанисту брюнетку в розхристаному шкіряному пальті... (2, с. 18, 19, 166-167), Вони таки не мають смальщю в голові, а Бога в череві, її сусіди, бо думають, що вона дурна. А Даруся не дурна вона солодка. Чому вона дурна, коли вона все розуміє, знає, що і як називається, який сьогодні день, скільки яблунь вродило в Маріїнім саду, скільки від Різдва до Різдва людей у селі родилося, а скільки вмерло?! ... А Параска - трохи не сповна розуму. I тому вона Божа людина, бо лиш вона собі вільно може говорити з Богом. А ми всі решту не такі, як Параска (3, с. 5, 5-6, 16).

Enimem-оксюморон допомагає повніше відтворити складність і суперечливість зображуваних явищ і подій, оскільки в цій мовній фігурі поєднуються два протилежні за змістом слова, що в сукупності дають нове поняття. Оксюморон виокремлено лише в творі М. Гримич: Він сам попросив Сатанаїла спокусити Адама $і$ Єву, щоб вони на все життя запам'ятали солодкий страх спокуси $і$ п'янке відчуття свободи i передали його всім наступним поколінням (1, с. 174). У лексичному значенні слова солодкий - «1. Який має приємний смак, властивий цукрові, меду. 3. Який викликає приємні відчуття, дає насолоду (про запах, аромат і т ін.)» [5, с. 1355] - виділяємо такі семи: 'приємний', 'солодкий', 'смак', 'відчуття', 'насолода', 'бажаний'; діаметрально протилежні семи виділяємо в семантиці («стан хвилювання, тривоги, неспокою, викликаний чеканням чого-небудь неприємного, небажаного» [5, с. 1400]) слова страх: 'стан', 'хвилювання', 'тривога', 'неспокій', 'неприємний', 'небажаний'. На підставі компонентного аналізу семантики виразу солодкий страх висновковуємо про його оксюморонну функцію в тексті М. Гримич.

Стилістична функція антонімічної градації, на думку 0. Пономарева [9, с.67] базується на відокремленні понять, виражених антонімами, на розмежуванні їх одне від одного в часі, просторі, за ознаками. Це допомагає митцеві яскравіше змалювати картину змін тих чи тих подій, образ персонажа: $М$ ж були вродливим народом, леді й джентльмени, відкритозорим, дужим і рослявим, самовладно-міцно вкоріненим у землю, з якої нас довго видирали з м'ясом, аж нарешті таки видерли, і ми розлетілись, розтрусились по всіх широтах обстрапаним пір'ям із розпоротих багнетами подушок (2, с. 100), А мені назавжди вбився в пам'ятку 
заздрий, знизу вгору, погляд колеги-киянина, невеличкого, юрливого полукровки з жіночно вузенькими, високо підібганими плічками, що невловно накидали йому профільну поставу горбаня, бідака ... став горбатим слупиком. А вояки там і правда як на підбір міфологічні велетні, розложисті гірські плато спин, рухомі стовбури стегон, міцні, з синюватим, проти оливкової засмаги, відливом, зуби, мов сама земля ожила йзаходила в ріст, ах які мужики, бенкет для зору! (2, с. 101).

Висновуємо, що найуживанішим художнім засобом протиставлення в аналізованих творах $\epsilon$ антитеза, також антоніми реалізують функції протиставлення, зіставлення, взаємного перетворення протилежностей.

\section{Висновки}

Антонімія різних мов здавна перебувала в центрі уваги як українських, так і зарубіжних мовознавців. Дослідники дійшли висновку, що в нашій свідомості абстрактні поняття закладено парами, кожне зі слів цієї пари викликає уявлення про друге. Через те антонімічні відношення виникають лише між словами, що об'єднані змістом на підставі їх протиставлення, протилежності.

На підставі компонентного аналізу опрацьовано явище антонімії в мові сучасної української жіночої прози, зокрема в творах Марини Гримич «Фріда», Оксани Забужко «Польові дослідження з українського сексу», Марії Матіос «Солодка Даруся». Потрібно зазначити, що кількість антонімічних рядів в аналізованих творах різна: найширше вони представлені в романі Марини Гримич (121 одиниця), у Марії Матіос (101 одиниця) і найменше - у «Польових дослідженнях 3 українського сексу» Оксани Забужко (58 фіксацій).

В аналізованих творах антоніми виконують функції антитези, градації та оксюморона (солодкий страх). Зауважимо, що в основі композиції романів «Фріда» Марини Гримич та «Солодка Даруся» М. Матіос лежить саме антитеза: Пустка оглушила й осліпила ї.. Дім був геть порожнім. Міфологічного дому-древа не було. Була руїна. Вона сиділа приголомшена і спустошена ... Відчула, як у неї всередині ожсває древо, як розгортаються прив'ялі листочки і набрякають бруньки, як у стовбурі починають пульсувати соки... Ось воно, древо, розгортає гілки, $і$ ось розпукуються бруньки, з яких вилазять липкі квітки, а з них пізніше народяться плоди (1, с. 17, 182); Вони таки не мають смальцю в голові, а Бога в 
череві, їі сусіди, бо думають, що вона дурна. А Даруся не дурна - вона солодка. Чому вона дурна, коли вона все розуміє, знає, що і як називається, який сьогодні день, скільки яблунь вродило в Маріїнім саду, скільки від Різдва до Різдва людей у селі родилося, а скільки вмерло?! (3, с. 5).

Отже, антоніми, репрезентовані в прозових творах Марини Гримич, Оксани Забужко та Марії Матіос, створюють різноплановість їхньої творчості, додають контрасту в опис, ліризму та динамізму художньому тексту.

\section{Список використаних джерел:}

1. Апресян Ю. Д. Лексическая семантика: синонимические средства языка. Москва: Наука, 1974. 358 с.

2. Бобух Н. М. Антоніми в українській поетичній мові. Полтава: РВЦ ПУСКУ, 2007. 312 с.

3. Бобух Н. М. Оксиморон у мові художньої літератури. Культура слова. Київ, 1988. Вип. 35. С. 32-34.

4. Василенко В. А. Функціонування синонімів і антонімів у поезіях Ігоря Муратова: автореф. дис. ... канд. філол. наук. Харків, 2000. 14 c.

5. Великий тлумачний словник сучасної української мови / уклад. і голов. ред. В. Т. Бусел. Київ: Перун, 2007. 1736 с.

6. Калита О. М. Мовні засоби вираження іронії в сучасній українській малій прозі: автореф. дис. ... канд. філол. наук. Київ, 2006. 23 c.

7. Коваль В. П. Експресивне використання антонімів в художньому мовленні. Українська мова і література в школі. 1986. № 4. С. 15-21.

8. Ковальов В. П. Експресивне використання антонімії в українському художньому мовленні. Українська мова і література в школі. 1986. № 9. С. 48-50.

9. Пономарів О. Д. Стилістика сучасної української мови. Тернопіль: Навчальна книга - Богдан, 2000. 248 с.

10.Реформатский А. А. Введение в языковедение / под ред. В. А. Виноградова. Москва: Аспект Пресс, 1996. 536 с.

11.Сучасна українська літературна мова: Лексикологія. Фонетика / А. К. Мойсієнко, О. В. Бас-Кононенко, В.В.Бондаренко та ін. Київ: Знання, 2010. 270 с. 
12.Сучасна українська літературна мова / А. П. Грищенко, Л. І. Мацько, М. Я. Плющ та ін.; за ред. А. П. Грищенка. Київ: Вища школа, 2002. 439 с.

13.Тараненко К. В. Прагмалінгвістичний аналіз антонімів у поезії Сергія Жадана. Мова i культура: науковий журнал. Київ: Видавничий дім Дмитра Бураго, 2013. Вип. 16. Т. 1 (163). С. 224-229.

14. Тараненко К. В. Прагматичні особливості антонімії прози Ліни Костенко. Літературний процес: структурно-семіотичні площини: матеріали Всеукраїнської наук. конференції / редкол.: Бондарева О. Є., Єременко О. В., Буянова І. Р. та ін. Київ: Київ. ун-т ім. Б. Грінченка, 2013. С. 199-202.

15.Тарасенко 0. Д. Контекстуальна антонімія та іï місце у творчості Володимира Винниченка. Наукові записки Національного університету «Острозька академія»: Сер. «Філологічна». 2014. Вип. 46. С. 261-264. URL: https://bit.ly/3BQijgQ (дата звернення: 05.11.2021)

\section{Список джерел фактичного матеріалу:}

1. Гримич М. Фріда. Київ: Дуліби, 2012.188 с.

2. Забужко О. Польові дослідження з українського сексу. Київ: Факт, 2007.176 с.

3. Матіос М. Солодка Даруся. Львів: ЛА «Піраміда», 2011.188 с. 